\title{
Transient Elevation of Messenger RNA Encoding Gastrin-releasing Peptide, a Putative Pulmonary Growth Factor in Human Fetal Lung
}

\author{
Eliot R. Spindel," Mary E. Sunday, ${ }^{\ddagger}$ Heinz Hofler, \\ Departments of Medicine, *Brigham and Women's Hospital and "Massachusetts General Hospital; Departments of Pathology, \\ ${ }^{\ddagger}$ Massachusetts General Hospital and ${ }^{\S}$ Tufts-New England Medical Center; Harvard Medical School and \\ Howard Hughes Medical Institute; Boston, Massachusetts 02115
}

\begin{abstract}
Gastrin-releasing peptide (GRP), the mammalian homologue of the amphibian peptide bombesin, is present in pulmonary neuroendocrine cells and appears to be a growth factor for both normal and neoplastic pulmonary cells. Previously we have reported the cloning of the messenger RNAs (mRNAs) and gene that encode human GRP. We now report that GRP mRNAs are markedly elevated in human fetal lung during the canalicular phase of pulmonary development (from $\sim 16$ to 30 wk gestation). By RNA blot and in situ hybridization analyses, GRP mRNAs were first detectable in fetal lung at 9-10 wk, plateaued at levels 25-fold higher than in adult lungs from 16 to $\sim 30$ wk and then declined to near adult levels by 34 wk gestation. By contrast, GRP peptide levels remain elevated until several months after birth. Consistent with this, in situ hybridization and immunohistochemical studies showed that GRP mRNA and peptide consistently colocalized in early gestation lung but that in neonatal lung, many cells that contained GRP peptide no longer contained GRP mRNA. The transient expression of high levels of GRP mRNAs during an $\sim 12$-wk phase of fetal lung development suggests that the secretion of GRP or its COOH-terminal peptides from pulmonary neuroendocrine cells may play a role in normal lung development.
\end{abstract}

\section{Introduction}

Gastrin-releasing peptide (GRP) ${ }^{1}$ is the 27 -amino acid mammalian homologue of the amphibian tetradecapeptide bombesin (1). GRP is widely distributed in mammalian lung, brain, and gastrointestinal (GI) tract (2-5). In the lung, GRP is located in the pulmonary neuroendocrine cells (6), and high levels are found in fetal lung, neonatal lung (7-10), and small cell carcinoma of the lung (SCCL) $(11,12)$. Recent studies

This work was presented in part at the 1986 National Meeting of the American Society for Clinical Investigation, Abstract 646A. Manuscript represents equal efforts of all authors.

Address reprint requests and correspondence to Eliot R. Spindel, M.D., Ph.D., Brigham and Women's Hospital, BRB-917, 75 Francis St., Boston, MA 02115.

Received for publication 24 September 1986 and in revised form 10 June 1987.

1. Abbreviations used in this paper: $\mathrm{ABC}$, avidin-biotin complex; CTEP, carboxy-terminal extension peptide; GI, gastrointestinal; GRP, gastrin-releasing peptide; SCCL, small cell carcinoma of the lung.

J. Clin. Invest.

(C) The American Society for Clinical Investigation, Inc.

0021-9738/87/10/1172א08 $\$ 2.00$

Volume 80, October 1987, 1172-1179 have suggested that GRP may be a growth factor for both normal and neoplastic pulmonary cells (13-15). Until its mitogenic effect on pulmonary cells was demonstrated, GRP's potential roles in lung were completely unknown. In brain GRP acts as a neurotransmitter and is involved in the regulation of sympathetic and parasympathetic functions (16). In the GI tract, GRP is located in the intrinsic neurons and acts as a paracrine hormone to stimulate the release of almost every known GI hormone including gastrin, somatostatin, insulin, and glucagon (17).

GRP is encoded by a single gene located on chromosome 18 (18). In neoplastic lung, the transcript of the GRP gene is alternately processed to yield three different GRP messenger RNAs (mRNAs) (18-20). These mRNAs all encode GRP, but in addition each encodes a different GRP carboxy-terminal extension peptide (CTEP). The role of the GRP CTEPs is still unknown but the strong conservation of amino acid sequences between rat and human GRP CTEPs suggests that they may have a physiologic function (Jim Battey, Bethesda Naval Hospital, National Cancer Institute, personal communication).

GRP has been shown to be a potent mitogen for Swiss 3T3 cells (21) acting through the phosphoinositol pathway (22). GRP is, in fact, often cited as an example of a prototypical growth factor which acts through its receptor and a $G$ protein to activate the formation of inositol trisphosphate and diacylglycerol $(23,24)$. Studies by Wiley et al. (13), Weber et al. (14), and Cuttitta et al. (15) have demonstrated that GRP stimulates the clonal growth of normal bronchial epithelial cells and the growth of SCCL cells both in vitro and in vivo. Additionally, Cuttitta et al. (15) have shown that an antibody to the GRP receptor blocks the growth of SCCL both in vitro and in vivo. Recent studies have also shown that GRP stimulates pancreatic and intestinal growth $(25,26)$.

Radioimmunoassay and immunohistochemical studies by Track and Cutz (7), Johnson et al. (8), Ghatei et al. (9), and Stahlman et al. (10) have shown that GRP levels are elevated in fetal lung and neonatal lung until 3 mo after birth. In acute hyaline membrane disease, levels of pulmonary GRP are decreased $(8,9)$, whereas in chronic bronchopulmonary dysplasia, GRP levels are increased (8).

Given the evidence that GRP is a pulmonary growth factor and the recognized importance of specific growth factors in normal development, we felt it important to use our recently developed GRP complementary DNA (cDNA) probes to examine GRP gene expression in the developing lung. Because mRNA levels are closely coupled to peptide synthesis, the measurement of GRP and mRNA levels more accurately reflects active peptide synthesis than does determination of GRP immunoreactivity. In situ hybridization can then be used in parallel to indicate precisely which and how many cells synthesize the GRP mRNAs. 


\section{Methods}

Lung tissue samples were collected from therapeutic abortions, autopsy and surgical specimens and were frozen or fixed immediately. Tissues $>10-12 \mathrm{~h}$ postmortem were not used. The adult lung surgical specimens were obtained less than $1 \mathrm{~h}$ postoperatively. For mRNA measurement, tissue was frozen on dry ice and stored in liquid nitrogen. For immunohistochemistry and in situ hybridization, tissue was fixed in $10 \%$ formaldehyde or $4 \%$ paraformaldehyde as described below. When quantities of tissue permitted, part of each specimen was processed for all procedures. In the case of suction abortions, the lobes of lung taken could not be identified due to fragmentation of the specimens. With the remaining fetal specimens, generally one lung was frozen for mRNA analyses and the other lung fixed for histochemical analyses. In the pediatric autopsy cases, tissue was taken from the medial portions of the upper lobes.

$m R N A$ determination. Total RNA was prepared by the method of Chirgwin et al. (27) by homogenization of lung tissue in guanidinium thiocyanate followed by centrifugation through $\mathrm{CsCl}$. Total RNA was subjected to electrophoresis through $1.5 \%$ (wt/vol) formaldehydeagarose gels and transferred to nitrocellulose by standard methods (28). Gels were stained with ethidium bromide to visualize the $28 \mathrm{~S}$ and $18 \mathrm{~S}$ ribosomal RNA bands to check for degradation and recovery of RNA. RNA from fetal lung was usually intact, but RNA from postnatal lung was frequently degraded, and such samples were not used for mRNA determinations or in situ hybridization. GRP RNAs were detected by hybridization to a GRP complementary RNA (cRNA) probe. The GRP cRNA probe was prepared by subcloning the Pst I-Hind III fragment of GRP cDNA pB12 (29) into pGEM4 (Promega Biotec, Madison, WI) and transcribing with SP6 polymerase as described by Melton et al. (30). Hybridization was in $5 \times$ SSC $(1 \times$ SSC $=0.15 \mathrm{M}$ $\mathrm{NaCl}, 0.015 \mathrm{M}$ Na Citrate); $5 \times$ Denhardt's solution (1× Denhardt's solution $=0.02 \%(\mathrm{wt} / \mathrm{vol})$ Ficoll-400, $0.02 \%(\mathrm{wt} / \mathrm{vol})$ bovine serum albumin, $0.02 \%$ (wt/vol) polyvinylpyrrolidone-40); $50 \%$ (vol/vol) formamide; $50 \mathrm{mM}$ sodium phosphate, $\mathrm{pH} 6.5 ; 0.2 \%$ (wt/vol) sodium dodecylsulfate (SDS) and sonicated, denatured salmon sperm DNA $(200 \mu \mathrm{g} / \mathrm{ml})$ at $65^{\circ} \mathrm{C}$ for $18 \mathrm{~h}$. Filters were washed at $65^{\circ} \mathrm{C}$ for $2 \times 15$ min in $2 \times$ SSC/0.2\% SDS followed by $2 \times 30$ min washes in $0.2 \times$ SSC $/ 0.2 \%$ SDS and exposed for $24-48 \mathrm{~h}$ at $-70^{\circ} \mathrm{C}$ with Kodak XAR film with an intensifying screen. Hybridization was quantified by densitometry by scanning the autoradiogram with a Chromoscan 3 (Joyce, Loebl and Co. Ltd., Gateshead, England).

SI nuclease mapping. S1 nuclease mapping was performed as described previously (18) with a uniformly labeled, single-stranded DNA probe using the method of Battey et al. (31). The probe used was a 260 nucleotide Pvu II fragment from GRP cDNA pB19 identical to Probe $C$ described by Sausville et al. (20). This probe spanned the region of alternate RNA splicing diagrammed in Fig. 1 and thus allowed differentiation of the three GRP mRNAs. S1-nuclease digests were subjected to electrophoresis on 0.4 -mm-thick $8 \%$ urea-acrylamide gels in parallel with a dideoxy sequence analysis of the $\mathrm{S} 1$ probe to allow exact sizing of the protected fragments.

In situ hybridization. In situ hybridization was performed as described previously (32). In brief, tissues were fixed for $2-4 \mathrm{~h}$ in $4 \%$ paraformaldehyde in phosphate-buffered saline (PBS) $(0.14 \mathrm{M} \mathrm{NaCl}$, $0.01 \mathrm{M}$ sodium phosphate, $\mathrm{pH} 7.0$ ), transferred to $30 \%$ sucrose in PBS for $16 \mathrm{~h}$ at $4^{\circ} \mathrm{C}$, frozen on powdered dry ice, and stored in a liquid nitrogen freezer. Tissue sections were cut on a cryostat at 5-10 $\mu \mathrm{m}$, placed onto prepared slides, and baked overnight at $42^{\circ} \mathrm{C}$. Slides were then rehydrated with PBS, treated with $0.3 \%$ (vol/vol) Triton X-100, proteinase $\mathrm{K}$, and acetic anhydride. Sections were prehybridized in $50 \%$ (vol/vol) formamide, $2 \times \mathrm{SSC}$ at $37^{\circ} \mathrm{C}$ for at least $10 \mathrm{~min}$. Hybridization was carried out with the pB12 GRP cRNA probe prepared as described above. $\left[{ }^{32} \mathrm{P}\right]-$ or $\left[{ }^{35} \mathrm{~S}\right]$-labeled probe $\left(5 \times 10^{5} \mathrm{cpm}\right)$ was applied to each tissue section in a volume of $10 \lambda$ of hybridization buffer ( $50 \%$ formamide, $10 \%$ dextran sulfate, $2 \times$ SSC, $0.5 \%$ SDS, $10 \times$ Denhardt's solution, $0.5 \% \mathrm{Na}$ pyrophosphate, $50 \mathrm{mM}$ Tris [pH 7.5], and $250 \mu \mathrm{g} / \mathrm{ml}$ sonicated, denatured salmon sperm DNA). Coverslips were applied and slides were incubated in a moist closed chamber at $42^{\circ} \mathrm{C}$ for $12-16 \mathrm{~h}$. Slides were washed in $4 \times \mathrm{SSC}$ at $37^{\circ} \mathrm{C}$ for $20 \mathrm{~min} \times 3$, treated with RNAse $A$ to digest any remaining unhybridized probes, and then washed sequentially in $2 \times$ SSC and $0.1 \times$ SSC for $30 \mathrm{~min}$ at $37^{\circ} \mathrm{C}$. Sections were then dehydrated in ethanols, air-dried, and dipped in Kodak NTB-2 autoradiographic emulsion. Slides were exposed for 7 $\mathrm{d}$ and developed and counterstained with methyl green.

To analyze semiquantitatively the number of GRP mRNA-containing cells present in tissue sections, we counted the number of in situ-positive neuroendocrine foci (which represent both single cells

A

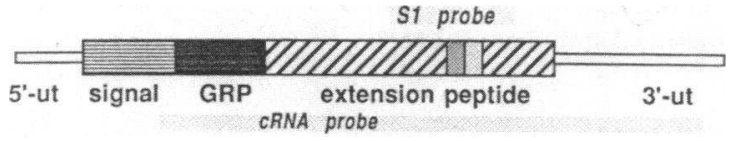

B

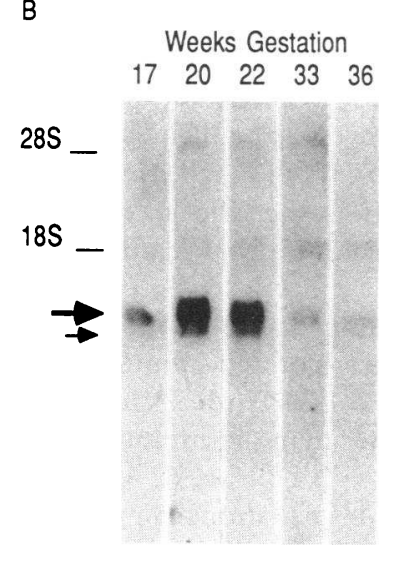

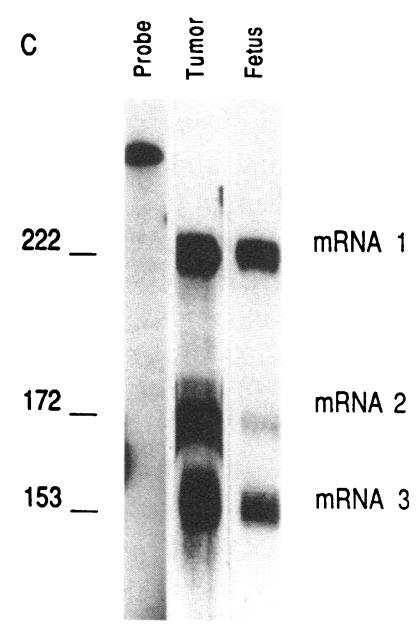

Figure 1. RNA (Northern) blot and S1-nuclease analysis of GRP RNA expression in fetal lung. $(A)$ Map of probes used for RNA blot and S1 analyses. The cRNA probe used for RNA blot analysis was $\sim 650$ bases. The single-stranded DNA probe used for $\mathrm{S} 1$ analysis was 288 bases and spanned the region of alternate splicing that produces the three different GRP mRNAs. $(B)$ Autoradiogram of Northern blot analysis of human fetal lung GRP mRNAs. $5 \mu \mathrm{g}$ of total RNA prepared from lungs of the gestational age in weeks shown were subjected to electrophoresis and hybridization to a GRP cRNA probe as described in Methods. Large arrow points to the major GRP mRNA species which are a mixture of all three GRP mRNAs. Small arrow points to the alternate polyadenylation species of the GRP mRNAs (E. Spindel, unpublished). The mobilities of the $28 \mathrm{~S}$ and $18 \mathrm{~S}$ ribosomal RNAs are shown for reference. $(C) \mathrm{S} 1$ nuclease analysis of alternate splicing of GRP and mRNAs in fetal lung RNA. Autoradiogram of single-stranded DNA probe protected from digestion by nuclease $\mathrm{S} 1$ through hybridization to GRP RNAs. Lane 1, probe alone; lane 2, polyadenylated RNA from a pulmonary carcinoid tumor $(100 \mathrm{ng})$; lane 3, polyadenylated RNA from a 16-wk human fetal lung $(5 \mu \mathrm{g})$. The nucleotide size of protected species is shown and was determined from a dideoxy sequencing ladder (not shown). By densitometric analysis the ratio of the three RNA species is $\sim 63: 8: 29$. 
and clusters of cells) in one entire section of each specimen (at least 10 low-power (100X) fields, and generally 20-40 low-power fields). Enumeration was performed by Dr. Sunday at two separate readings over $24 \mathrm{~h}$ apart which were generally reviewed by at least one other observer. Because single neuroendocrine cells could represent either isolated Kultschitzky type intramucosal neuroendocrine cells or cells in the peripheral portion of a neuroendocrine cell cluster (eg., neuroepithelial body) (33), both individual cells and discrete cell clusters were each counted as a single focus. Results were expressed both as a number of positive foci per $20 \mathrm{lpf}$ and also normalized as the number of positive foci per 100 airways.

The intensity of hybridization was estimated by counting at $1,000 \times$ with a micrometer grid the number of $\left[{ }^{35}\right.$ S $]$ grains in $100 \mu \mathrm{m}^{2}$ for 20 different random in situ foci to calculate grain density. For comparison of proximal to distal airways, we defined proximal airways as bronchi and large bronchioles entirely lined by columnar epithelium, and distal airways as smaller bronchioles and airways lined mostly by cuboidal epithelium and at most partially lined by columnar epithelium. Thus, in midgestation fetuses, primitive alveolar spaces were counted as distal airways, whereas in the neonates, the mature alveoli were not included (34). For these studies in situ hybridization analyses and immunohistochemistry were performed on serial sections of 13 cases. These included five early gestation fetal lung specimens (6-15 wk gestation), four midgestation specimens (20-24 wk gestation), and four neonatal specimens from infants aged 3-10 wk postnatal (with diagnoses of SIDS [two cases] and congenital heart disease [two cases]).

Immunohistochemistry. Immunohistochemistry was performed using an antiserum against amphibian bombesin that cross-reacted equally with the carboxy terminus of GRP (35). This antibody did not significantly cross-react with the bombesin analogues ranatensin and litorin or with substance $P$ (35). Bound antibody was visualized with the avidin-biotin complex (ABC) immunoperoxidase technique according to standard protocols (Vector Laboratories, Inc., Burlingame, CA) as described elsewhere (36). Controls consisted of nonimmune rabbit serum, or anti-bombesin antiserum preabsorbed with bombesin $(25 \mu \mathrm{g} / \mathrm{ml})$. Serial sections of two specimens of midgestation fetal lung were also stained for chromogranin $\mathrm{A}$ (37) by the $\mathrm{ABC}$ immunoperoxidase technique using a well-characterized mouse monoclonal antibody (Hybridtech Inc., San Diego, CA). Immunoperoxidase-stained cells were quantitated as described above for cells identified by in situ hybridization.

Unless otherwise stated for immunohistochemistry, tissues were routinely fixed in $10 \%$ buffered formalin and processed into paraffin blocks that were cut at a thickness of $5 \mu \mathrm{m}$ onto chromgel-coated slides. For immunohistochemistry and in situ hybridization on serial sections of the same lung slices, tissues were fixed in $4 \%$ paraformaldehyde and cut as described above.

\section{Results}

The diagnoses and ages of the patients from whom the lung samples derived are summarized in Tables I and II. Of 41 samples collected, 8 were analyzed for GRP mRNA content alone, 15 for GRP immunostaining alone, and 18 for both (Tables I and II). GRP mRNAs were not quantitated in samples that showed RNA degradation on ethidium bromidestained agarose gels. For quantitative in situ hybridization analysis, 13 additional samples were analyzed as described in Methods.

GRP mRNAs were analyzed by three different methods. Northern blot analyses were performed to quantitate the total amount of all GRP mRNAs present in the lung (Tables I and II; Fig. $1 B$ ). S1-nuclease analyses were performed to determine the ratios of the three different GRP mRNAs (Fig. 1 C). In situ hybridization analyses were performed to determine cell type and relative number of cells containing GRP mRNAs (Fig. 2).
Table I. Description of Prenatal Lung Samples

\begin{tabular}{|c|c|c|c|c|}
\hline $\begin{array}{l}\text { Case } \\
\text { no. }\end{array}$ & $\begin{array}{l}\text { Gestational } \\
\text { age }\end{array}$ & $\begin{array}{l}\text { Clinical } \\
\text { diagnosis }\end{array}$ & $\begin{array}{l}\text { GRP-immuno } \\
\text { index* }\end{array}$ & $\begin{array}{l}\text { GRP } \\
\text { mRNA }\end{array}$ \\
\hline & $w k$ & & & \\
\hline 1 & 9.5 & $\mathbf{S}$ & ND & 107 \\
\hline 2 & 10.5 & $\mathbf{S}$ & ND & 21 \\
\hline 3 & 12.0 & $S$ & 0 & ND \\
\hline 4 & 13.0 & $S$ & 0 & 10 \\
\hline 5 & 15.5 & S & 0 & ND \\
\hline 6 & 16.0 & PG & 6 & 345 \\
\hline 7 & 16.0 & $\mathbf{S}$ & ND & 947 \\
\hline 8 & 17.0 & PG & ND & 136 \\
\hline 9 & 17.5 & PG & 11 & 1,302 \\
\hline 10 & 18.0 & PG & 9 & 912 \\
\hline 11 & 18.0 & PG & 40 & ND \\
\hline 12 & 19.0 & PG & 8 & ND \\
\hline 13 & 19.0 & PG & 9 & 1,087 \\
\hline 14 & 19.0 & PG & 12 & ND \\
\hline 15 & 19.0 & PG & ND & 794 \\
\hline 16 & 19.5 & PG & 28 & ND \\
\hline 17 & 20.0 & PG & 53 & 1,611 \\
\hline 18 & 21.0 & PG & 85 & ND \\
\hline 19 & 21.5 & PG & 42 & ND \\
\hline 20 & 22.0 & PG & 11 & 1,302 \\
\hline 21 & 22.0 & PG & 14 & 838 \\
\hline 22 & 22.0 & PG & 39 & 614 \\
\hline 23 & 22.0 & PG & 10 & ND \\
\hline 24 & 22.0 & PG & ND & 811 \\
\hline 25 & 22.0 & PG & ND & 607 \\
\hline 26 & 22.0 & PG & ND & 248 \\
\hline 27 & 23.0 & PG & 44 & 379 \\
\hline
\end{tabular}

PG, prostaglandin infusion-induced abortion. S, suction abortion. * GRP-immuno index, as detailed in the text, is the number of GRPpositive neuroendocrine cell foci stained by immunoperoxidase per 20 low-power $(100 \times)$ fields.

‡ GRP-mRNA hybridization on Northern blots was quantitated by scanning densitometry as detailed in the text, and values are given in arbitrary densitometric units.

By Northern blot analyses GRP mRNA in human fetal lung was markedly elevated by 17 wk gestation, peak levels were obtained from 19 to $26 \mathrm{wk}$, and by 33 wk gestation levels had already markedly declined (Fig. $1 B$ ). S1-nuclease analysis demonstrated that fetal lung expresses all three GRP mRNAs in similar ratios as has been previously reported for other normal and neoplastic GRP-containing tissues, including both benign pulmonary carcinoids and SCCLs $(18,20)$ (Fig. $1 C$ ). As determined by S1-nuclease analysis, the ratios of the three GRP mRNAs present in fetal lung did not change during development (data not shown).

The overall developmental time course of GRP mRNA and peptide determined by Northern blot and immunostaining in lung is shown in Fig. 3. Levels of GRP mRNA appeared slightly earlier and rose slightly faster than did immunostaining, while both peaked from $\sim 16$ to $26-30$ weeks. Most importantly however, GRP mRNA levels had dropped markedly by 34 wk gestation whereas GRP peptide levels as indicated by GRP immunostaining remained elevated until 6 mo after 
Table II. Description of Postnatal Lung Samples

\begin{tabular}{|c|c|c|c|c|}
\hline $\begin{array}{l}\text { Case } \\
\text { no. }\end{array}$ & $\begin{array}{l}\text { Length of } \\
\text { gestation/length } \\
\text { of postnatal life }\end{array}$ & Clinical diagnosis & $\begin{array}{l}\text { GRP-immuno } \\
\text { index }\end{array}$ & $\begin{array}{l}\text { GRP } \\
\text { mRNA }^{\ddagger}\end{array}$ \\
\hline 28 & $28 w k / 5 w k$ & $\begin{array}{l}\text { Bronchopulmonary } \\
\text { dysplasia }\end{array}$ & 28 & 80 \\
\hline 29 & 33 wk/0 & Giant cell pneumonitis & 44 & 79 \\
\hline 30 & $34 \mathrm{wk} / 1 \mathrm{~h}$ & $\begin{array}{l}\text { Anencephaly; } \\
\text { pulmonary } \\
\text { hypoplasia }\end{array}$ & 4 & 170 \\
\hline 31 & $37 \mathrm{wk} / 5 \mathrm{~d}$ & $\begin{array}{l}\text { Congenital heart } \\
\text { disease; trisomy 18; } \\
\text { hyaline membrane } \\
\text { disease }\end{array}$ & 24 & D \\
\hline 32 & $37 \mathrm{wk} / 1 \mathrm{wk}$ & $\begin{array}{l}\text { Renal aplasia; } \\
\text { pulmonary } \\
\text { hypoplasia }\end{array}$ & 22 & 34 \\
\hline 33 & $\begin{array}{l}34 \mathrm{wk} / 2.5 \\
\mathrm{mo}\end{array}$ & $\begin{array}{l}\text { Congenital heart } \\
\text { disease; } \\
\text { bronchopneumonia }\end{array}$ & 24 & D \\
\hline 34 & $40 \mathrm{wk} / 3 \mathrm{mo}$ & $\begin{array}{l}\text { Sudden infant death } \\
\text { syndrome }\end{array}$ & 26 & D \\
\hline 35 & $34 \mathrm{wk} / 5 \mathrm{mo}$ & $\begin{array}{l}\text { Congenital muscular } \\
\text { dystrophy; } \\
\text { bronchopneumonia }\end{array}$ & 20 & 20 \\
\hline 36 & $36 \mathrm{wk} / 7 \mathrm{mo}$ & $\begin{array}{l}\text { Congenital heart } \\
\text { disease; pulmonary } \\
\text { congestion }\end{array}$ & 13 & D \\
\hline 37 & $\mathrm{NK} / 3 \mathrm{yr}$ & $\begin{array}{l}\text { Hemolytic uremic } \\
\text { syndrome; normal } \\
\text { lungs }\end{array}$ & 2 & 50 \\
\hline 38 & $\mathrm{NK} / 4 \mathrm{yr}$ & $\begin{array}{l}\text { Cardiac fibrosarcoma; } \\
\text { pleural effusions }\end{array}$ & 0 & ND \\
\hline 39 & $\mathrm{NK} / 11 \mathrm{yr}$ & $\begin{array}{l}\text { Drowning; } \\
\text { pneumothorax }\end{array}$ & 2 & ND \\
\hline 40 & $\mathrm{NK} / 58 \mathrm{yr}$ & $\begin{array}{l}\text { Lung squamous cell } \\
\text { carcinoma; lung } \\
\text { used (right) was } \\
\text { normal }\end{array}$ & 0 & 15 \\
\hline 41 & $\mathrm{NK} / 67 \mathrm{yr}$ & $\begin{array}{l}\text { Lung adenocarcinoma; } \\
\text { lung used (left) was } \\
\text { normal }\end{array}$ & 0 & 25 \\
\hline
\end{tabular}

$D$, degraded; NK, not known.

* GRP-immuno index, as detailed in the text, is the number of GRPpositive neuroendocrine cell foci stained by immunoperoxidase per 20 low-power $(100 \times)$ fields.

‡ GRP-mRNA hybridization on Northern blots was quantitated by scanning densitometry as detailed in the text and values are given in arbitrary densitometric units.

birth. This agrees with previous radioimmunoassay determinations of bombesinlike immunoreactivity in neonatal lung $(7,9)$.

In situ hybridization combined with immunohistochemistry localized GRP mRNAs and peptide to pulmonary neuroendocrine cells and pulmonary neuroepithelial bodies in both bronchi and bronchioles but not in primitive air saccules nor (in neonates) in mature alveoli. As shown in Fig. $2 A$, immunoperoxidase studies performed with anti-bombesin anti- serum revealed numerous foci of neuroendocrine cells staining positively for GRP immunoreactivity in a 23-wk fetal lung. In Fig. $2 B$, absorption of the anti-bombesin antiserum with bombesin $(25 \mu \mathrm{g} / \mathrm{ml})$ blocked staining in serial sections. The GRP-positive neuroendocrine cells were localized both proximally and distally, predominantly in bronchioles, and represented about one third of the "total" neuroendocrine cell population as assessed by immunoperoxidase staining of two of these lungs with a well-characterized monoclonal antibody to chromogranin A (37) (data not shown).

In situ hybridization on serial sections of midgestation fetal lung also demonstrated numerous prominent foci of neuroendocrine cells which hybridized to the labeled GRP cRNA probe (Fig. $2 C$ ). In contrast, control sections incubated with the corresponding radiolabeled GRP cRNA "sense" probe (identical to, rather than complementary to, GRP mRNA contained in the tissue sections) did not hybridize to the same mRNA-positive foci in serial sections (Fig. $2 \mathrm{D}$ ). As determined by serial tissue sections or by colocalization of both GRP peptide and GRP mRNA in the same tissue section, GRP mRNA and immunoreactivity consistently colocalized.

In situ hybridization analysis of early gestation lung $(9.5$ wk) showed extensive hybridization exclusively in proximal airways (Fig. $2 E$ ). More distal airways, which at this early stage of lung development had not yet started to bifurcate, showed no GRP hybridization. Immunohistochemistry of serial sections (Fig. $2 F$ ) showed that GRP peptide colocalized to $80 \%$ of these same cells, though the immunoperoxidase signal was much less than at later stages and could only be detected after pretreatment of the tissue sections with $0.3 \%$ Triton $X-100$. Thus Triton $X-100$ pretreatment was used for all of the quantitations on serial sections (Figs. 4 and 5). Neither GRP peptide nor mRNA were detected in 6 wk fetal lung which did however contain cells positive for chromogranin A immunoreactivity. The other early gestation lungs (10.5-15 wk) demonstrated intense hybridization in proximal airways almost always at points of bifurcation and occasional foci with less intense hybridization in distal airways (see below). Most of the proximal foci were also positive for GRP peptide, whereas as few as $25 \%$ of distal foci contained detectable GRP peptide (Fig. 4).

Immunohistochemical analysis of neonatal lung showed multiple foci of GRP immunostaining cells both proximally and distally similar to midgestation fetal lung, again predominantly in bronchioles at points of bifurcation. Unlike early and midgestational lung, however, many GRP-immunoreactive foci did not demonstrate any corresponding in situ hybridization signal on serial sections (Fig. 3, $G$ and $H$ ). Further, in neonatal lung as compared with fetal lung there were stronger hybridization signals in distal lung as compared with proximal lung.

To quantify the apparent decrease of in situ hybridizing foci in neonatal lung, the number of GRP mRNA hybridizing foci were counted and compared with GRP immunostaining foci in serial sections. The total number of foci counted were normalized to the number of airways per section counted to control for dilutional effects of increased lung size with development (Fig. 4). In early and midgestation lung there were more hybridizing foci than immunostaining foci; in neonatal lung this reversed and there were fewer hybridizing foci than immunostaining foci. This result agrees with the data shown in Fig. 3 and confirms the decrease in GRP mRNA levels deter- 

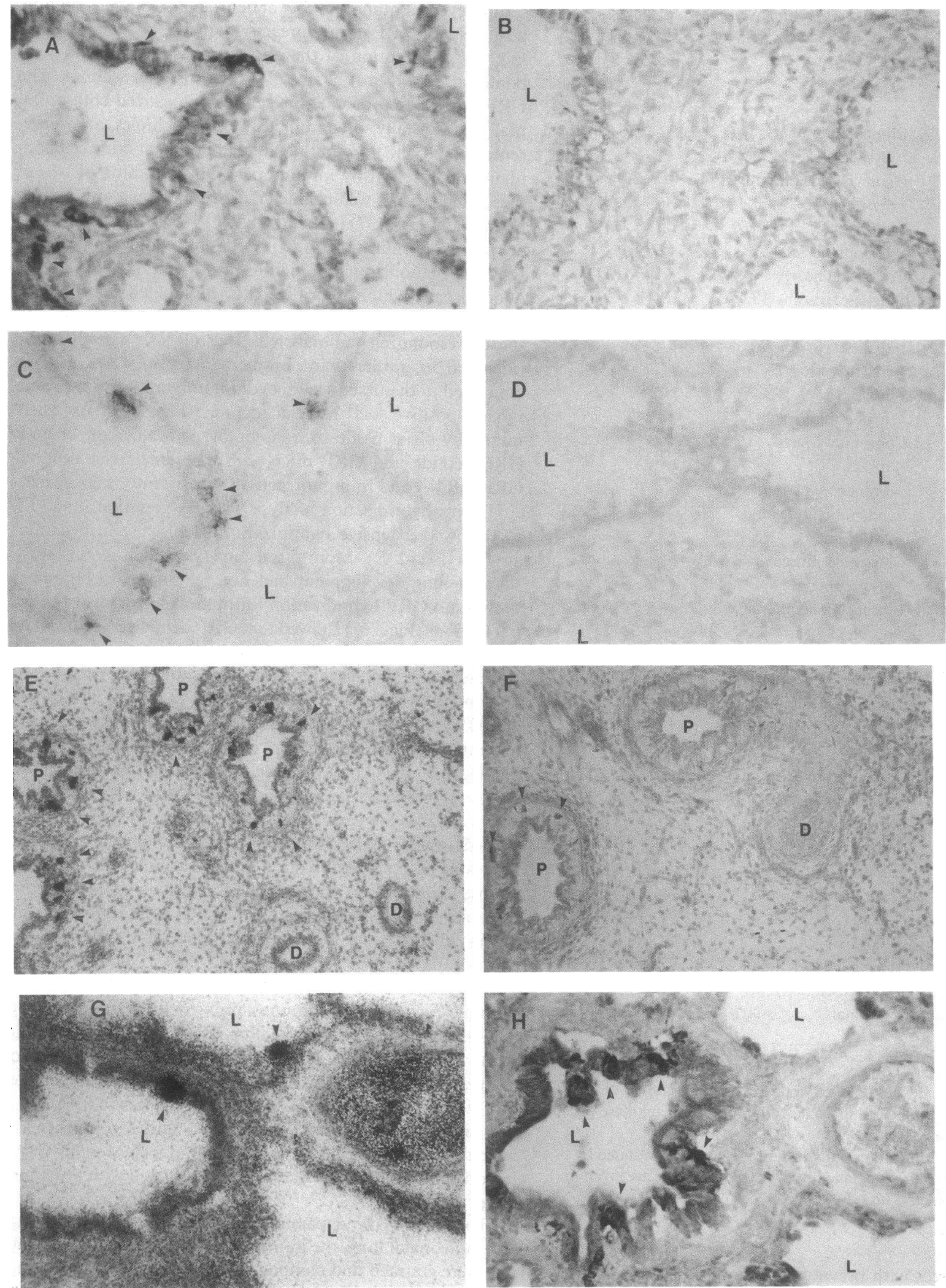

Figure 2. GRP immunohistochemistry and in situ hybridization in fetal and neonatal lung. $(A)$ Immunoperoxidase with anti-bombesin antiserum (1:500 dilution) of 23-wk gestation lung demonstrates numerous clusters of GRP-positive neuroendocrine cells in a bronchiole $(\times 160)$. Arrows point to positively stained cells. ( $L$, air way lumen) $(B)$ Serial section to $A$ analyzed with the same antiserum (1:500) preabsorbed with bombesin antigen $(25 \mu \mathrm{g} / \mathrm{ml})$ demonstrates no immunostaining $(\times 160),(C)$ In situ hybridization of serial section to $A$ with $\left[{ }^{35} \mathrm{~S}\right]$-labeled GRP cRNA (anti-sense orientation which is complementary to mRNAs) demonstrates multiple hybridizing foci corresponding to GRP-positive neuroendocrine cells $(\times 160)$. Arrows point to hybridizing cells. $(D)$ Serial section to $C$ analyzed with $\left[{ }^{35} S\right]$-labeled control GRP cRNA (sense orientation which is identical to mRNAs) is devoid of any specific hybridization 


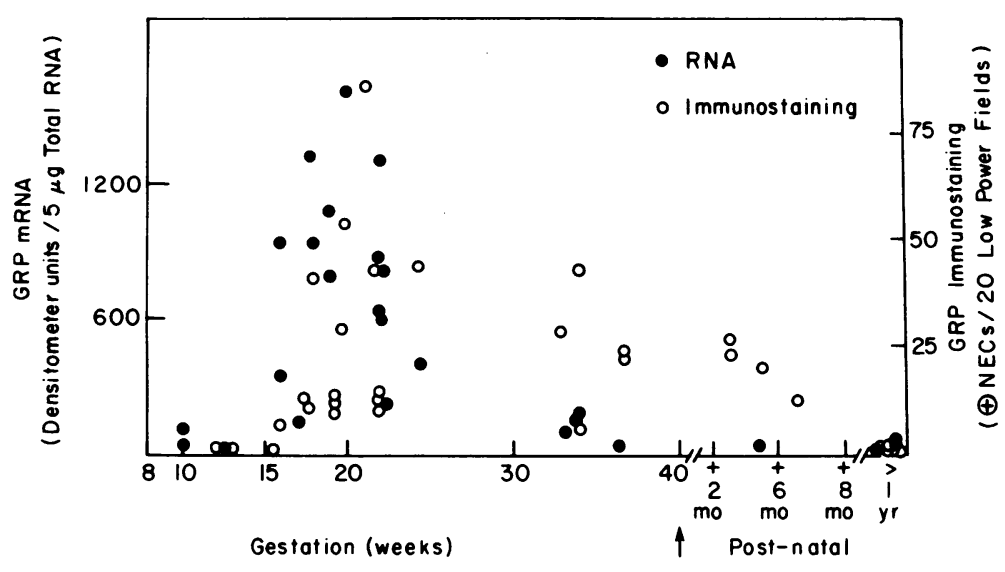

Figure 3. Time course of GRP mRNA and immunostaining in fetal lung. GRP mRNA was determined by Northern blot analyses of $5 \mu \mathrm{g}$ samples of total lung RNA. GRP immunostaining was quantitated by counting positive neuroepithelial cell foci (+NECs) in 20 lowpower $(100 \times)$ fields as described in the text. Age is shown on lower axis. Arrow indicates pre- vs. postnatal periods. Clinical diagnosis are shown in Table I and II. mined by Northern blot analysis. In addition this suggests that the decrease in GRP mRNA is due in part to fewer cells actually synthesizing GRP mRNA.

To confirm the apparent developmental shift in GRP mRNA hybridization from predominantly proximal expression to predominantly distal expression, grain density of the hybridizing signal was determined (Fig. 5). In early gestation, hybridization was most intense in proximal lung. In the neonate, when relatively fewer foci of hybridization were apparent, hybridization was more intense distally than proximally (Fig. 5). This suggests that in the developing lung, activation of GRP gene expression follows a proximal to distal progression.

\section{Discussion}

Northern blot S1-nuclease and in situ hybridization analyses demonstrate that GRP mRNAs are markedly elevated in fetal lung tissue from 16 to $\sim 26-30$ wk gestation. GRP immunostaining is also elevated during that period but remains elevated for 6 mo after birth. The pattern and time course of GRP immunostaining that we have observed is consistent with previous reports (7-10) that have determined pulmonary GRP peptide levels both by immunohistochemistry and by radioimmunoassay. Given that GRP peptide levels remain elevated until several months after birth, it is surprising that the GRP gene itself, as indicated by mRNA levels, is activated for such a short time period. We hypothesize that the kinetics of ongoing GRP synthesis and possibly secretion correlate more closely with mRNA levels than with peptide levels because peptide levels may reflect GRP stored long after the critical growth phases have ended. Thus GRP may be physiologically active during a relatively short, $\sim 12-14$-wk period of lung development.

This period of gestation during which the GRP gene is activated corresponds rather precisely to the canalicular phase of pulmonary development as defined by Reid et al. (34) and Boyden (38). This phase is characterized by considerable extension and branching of the respiratory bronchioles and air- spaces with concomitant epithelialization and capillary invasion. At the end of this period, the lung is theoretically able to maintain respiration and the differentiation of type 2 pneumocytes with synthesis of surfactant has just commenced.

Because of the difficulty in obtaining fresh $(<3 \mathrm{~h}$ postmortem) human lung specimens without pathology between 24 and 32 wk gestation, the precise time when GRP gene activation ends cannot be exactly determined. Nonetheless, it is apparent from our experiments that during the interval between 26 and 30 wk gestation, GRP mRNA levels markedly decrease. It must also be noted that there was a wide range of pathology in the postnatal lung specimens, including primary pulmonary pathology, and thus our observations cannot be completely representative of normal development.

Northern blot and S1-nuclease analyses indicate that the GRP mRNAs expressed in fetal lung are similar to the GRP mRNAs that have been characterized by molecular cloning in pulmonary carcinoids and SCCL (18-20, 29) (Fig. 1). Densitometric analysis of the three GRP mRNAs showed no change with development (data not shown) and the ratio observed in fetal lung is the same as we have observed in lung neoplasms and in thyroid medullary carcinoma (18). Thus, fetal lung expresses all three GRP mRNAs and potentially the three resulting GRP extension peptides. Whether there is variability between cells as to the ratio of GRP mRNA forms expressed remains to be determined as does the potential role of the GRP extension peptides in lung.

In situ hybridization confirmed the presence of abundant GRP mRNA and peptide immunoreactivity in midgestation fetal lung and localized the mRNA to neuroendocrine cells either singly or in clusters most intensely localized at the branching points of respiratory bronchioles (Fig. $2 \mathrm{C}$ ). This was especially clear in in situ hybridization analyses of earlygestation (9-12 wk) lungs in which almost all of the hybridization was in proximal airways at branch points and very little if any hybridization was visible in distal airways (Fig. $2 E$ ). In neonatal lung, many foci of neuroendocrine cells which by immunoperoxidase still contained GRP peptide were no signal $(\times 160) .(E)$ In situ hybridization of 9.5-wk gestation fetal lung demonstrates multiple hybridizing foci in proximal airways $(P)$ as compared with distal airways $(D)$. Arrows point to hybridizing cells which are predominantly located at branch points $(\times 160)$. $(F)$ Serial section to $E$ showing immunoperoxidase with anti-bombesin antiserum (1:500 dilution) $(\times 160)$. (G) In situ hybridization of 1 mo neonatal lung demonstrates relatively few foci of hybridization as compared with the multiple foci of immunostaining in the serial section depicted in $H$. $(\times 160)$. $(H)$ Serial section to $G$ showing immunoperoxidase with anti-bombesin antiserum (1:500 dilution). Arrows point to multiple immunoreactive foci $(\times 160)$. 


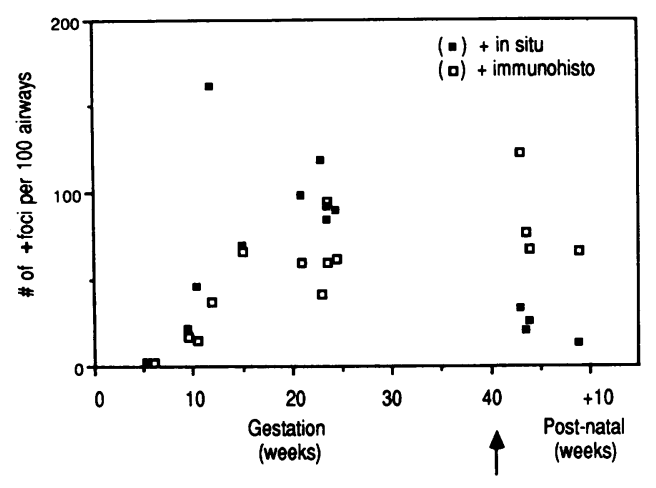

Figure 4. Time course of GRP in situ hybridizing and immunostaining foci normalized to airway number. GRP mRNA or peptide containing foci were quantitated as described in Methods. Age is shown on lower axis. An arrow indicates pre- vs. postnatal periods.

longer positive for GRP mRNA by in situ hybridization (Fig. 2, $G$ and $H$ ). This confirms the RNA blot analyses of GRP mRNA levels in total lung which indicated that GRP mRNA levels decreased more rapidly than did GRP peptide levels (Fig. 3). This is further confirmed by quantitating the number of GRP immunoperoxidase positive and GRP in situ positive foci in early-gestation, midgestation, and neonatal lung samples (Fig. 4). To control for any dilutional effects of more rapid increases in lung parenchyma than in the number of neuroendocrine cells, these data were normalized to the number of airways on the sections counted. This yielded a similar curve to that seen in Fig. 3, indicating that mRNA levels decline earlier than peptide levels and that the decrease in GRP mRNA levels derives in part from fewer cells both proximally and distally actually synthesizing GRP mRNA.

In early gestation lung GRP in situ hybridization was most intense in proximal lung, but with lung development, the hybridization intensity as well as the number of hybridizing foci increased in distal lung. This was quantified by comparing grain density in proximal versus distal airways in developing lung (Fig. 5). In the neonate there was an approximately twofold increase in the relative hybridization in distal airways as compared with early fetal lung. This suggests that the GRP gene is activated in a proximal to distal progression perhaps in parallel with the development and differentiation of the respiratory bronchioles. Thus, the relative decrease in grain density proximally suggests that decreased GRP mRNA levels in post-

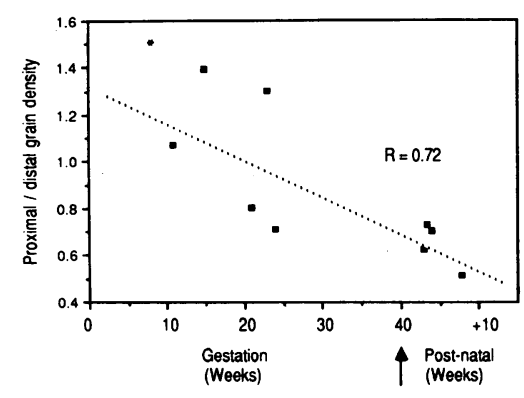

Figure 5. Time course of relative intensity of proximal vs. distal in situ hybridization in developing lung. Grain density of hybridizing foci and identification of airways as proximal or distal was determined as described in Methods. *Indicates point for which hybridization was observed only in proximal airways. Correlation coefficient for a least squares regression analysis was 0.72 with $P<0.05$. natal lungs is partly due to decreased mRNA synthesis by individual cells as well as due to reduced number of cells that actively synthesize GRP mRNA.

The peak expression of GRP mRNA coinciding with the canalicular phase of lung development suggests that GRP has a role in development predominantly at this time. Our observations, combined with growth-promoting effects on Swiss 3T3 cells (21) and pulmonary epithelial cells (13), are highly suggestive that GRP gene activation plays a role in normal lung growth. The detection of GRP mRNA in bronchioles mainly at points of airway bifurcation by in situ hybridization suggests that GRP gene products may play a role in inducing the formation of new primitive air saccules along respiratory bronchioles as well as on continued growth of airway epithelium during extension of both central and peripheral airways. The absence of GRP from either primitive air saccules or mature alveoli suggests that GRP does not have a predominant role in growth of the alveolar units after they have been initiated. Other paracrine and endocrine functions of GRP, such as vasoactive effects or the release of other local growth factors or hormones, cannot be excluded. Determination of the precise role of GRP in lung development awaits further investigations such as organ culture and animal studies. In the latter regard, perhaps the neonatal hamster which has been reported to have similar distributions of GRP in small airways as humans (39) may prove useful.

\section{Acknowledgments}

We thank Jim Battey and Ed Sausville for providing the S1 probe used in Fig. $3 B$ and we thank Lynne Reid for valuable discussions on lung development. We also thank Janet Price and Leslie Rees for providing the anti-bombesin antisera, and we thank Rapin Osathanondh and the Department of Gynecologic Pathology at the Brigham and Women's Hospital for assistance in obtaining postmortem fetal lung tissue. Appreciation is also extended to the Departments of Pathology at the Massachusetts General Hospital and Children's Hospital Medical Center in Boston for providing access to tissues from postmortem and surgical specimens. These studies were conducted under the guidelines of each of the participating hospital's human subject and pathologic tissue committees.

This work was supported by grants R23-CA39237, R23-AM36036, and CA-17289.

\section{References}

1. Spindel, E. R. 1986. Mammalian bombesin-like peptides. Trends Neurosci. 9:130-133.

2. Roth, K. A., E. Weber, and J. D. Barchas. 1982. Distribution of gastrin releasing peptide- bombesin-like immunostaining in rat brain. Brain Res. 251:277-282.

3. Dockray, G. J., C. Vaillant, and J. H. Walsh. 1979. The neuronal origin of bombesin-like immunoreactivity in the rat gastrointestinal tract. Neuroendocrinology. 4:1561-1568.

4. Walsh, J. H., H. C. Wong, and G. J. Dockray. 1979. Bombesinlike peptides in mammals. Fed. Proc. 38:2315-2319.

5. Wharton, J., J. M. Polak, S. R. Bloom, M. A. Ghatei, E. Solcia, M. R. Brown, and A. G. E. Pearse. 1978. Bombesin-like immunoreactivity in the lung. Nature (Lond.). 273:769-770.

6. Cutz, E., W. Chan, and N. S. Track. 1981. Bombesin, calcitonin and leu-enkephalin immunoreactivity in endocrine cells of the human lung. Experientia (Basel). 37:765-767.

7. Track, N. S., and E. Cutz. 1982. Bombesin-like immunoreactivity in developing human lung. Life Sci. 30:1553-1556. 
8. Johnson, D. E., J. E. Lock, R. P. Elde, and T. R. Thompson. 1982. Pulmonary neuroendocrine cells in hyaline membrane disease and bronchopulmonary dysplasia. Pediatr. Res. 16:446-454.

9. Ghatei, M. A., M. N. Sheppard, S. Henzen-Logman, M. A. Blank, J. M. Polak, and S. R. Bloom. 1983. Bombesin and vasoactive intestinal polypeptide in the developing lung: marked changes in acute respiratory distress syndrome. J. Clin. Endocrinol. \& Metab. 57:12261232.

10. Stahlman, M. T., A. G. Kasselberg, D. N. Orth, and M. E. Gray. 1985. Ontogeny of neuroendocrine cells in human fetal lung. II. An immunohistochemical study. Lab. Invest. 52:52-60.

11. Moody, T. W., C. B. Pert, A. F. Gazdar, D. N. Carney, and J. D. Minna. 1981. High levels of intracellular bombesin characterise human small-cell lung carcinoma. Science (Wash. DC). 214:12461248.

12. Erisman, M. D., R. I. Linno, O. Hernandez, R. P. DiAngustine, and L. H. Lazarus. 1982. Human lung small cell carcinoma contains bombesin. Proc. Natl. Acad. Sci. USA. 79:2379-2383.

13. Willey, J. C., J. F. Lechner, and C. C. Harris. 1984. Bombesin and the C-terminal tetradecapeptide of gastrin-releasing peptide are growth factors for normal human bronchial epithelial cells. Exp. Cell Res. 153:245-248.

14. Weber, S., J. E. Zuckerman, D. G. Bostwick, K. G. Bensch, B. I. Sikic, and T. A. Raffin. 1985. Gastrin-releasing peptide is a selective mitogen for small cell lung carcinoma in vitro. J. Clin. Invest. 75:306309.

15. Cuttitta, F., D. N. Carney, J. Mulshine, T. W. Moody, J. Fedorko, A. Fischler, and J. D. Minna. 1985. Bombesin-like peptides can function as autocrine growth factors in human small cell lung cancer. Nature (Lond.). 316:823-826.

16. Tache, Y., and M. Brown. 1982 On the role of bombesin in homeostasis. Trends Neurosci. 5:431-433.

17. McDonald, T. J., M. A. Ghatei, S. R. Bloom, T. E. Adrian, T. Mochizuki, C. Yanaihara, and N. Yanaihara. 1983. Dose-response comparisons of canine plasma gastroenteropancreatic hormone responses to bombesin and the porcine gastrin-releasing peptide. Regul. Pept. 5:125-137.

18. Spindel, E. R., M. D. Zilberberg, and W. W. Chin. 1987. Analysis of the gene and multiple messenger ribonucleic acids (mRNAs) encoding human gastrin-releasing peptide: alternate RNA splicing occurs in neural and endocrine tissue. Mol. Endocrinol. 1:224-232.

19. Spindel, E. R., M. D. Zilberberg, J. F. Habener, and W. W. Chin. 1986. Two prohormones for gastrin-releasing peptide are encoded by two mRNAs differing by 19 bases. Proc. Natl. Acad. Sci. USA. 83:19-23.

20. Sausville, E. A., A. M. Lebacq-Verheyden, E. R. Spindel, F. Cuttita, A. F. Gazdar, and J. F. Battey. 1986. Expression of the gastrin-releasing peptide gene in human small cell lung cancer. J. Biol. Chem. 261:2451-2457.

21. Rozengurt, E., and J. Sinnett-Smith. 1983. Bombesin stimulation of DNA synthesis and cell division in cultures of Swiss 3T3 cells. Proc. Natl. Acad. Sci. USA. 80:2936-2940.

22. Brown, K. D., J. Blay, R. F. Irvine, J. P. Heslop, and M. J. Berridge. 1984. Reduction of epidermal growth factor receptor affinity by heterologous ligands: evidence for a mechanism involving the breakdown of phosphoinositides and the activation of protein kinase C. Biochem. Biophys. Res. Commun. 123:377-384.

23. Zachary, I., J. W. Sinnett-Smith, and E. Rozengurt. 1986. Early events elicited by bombesin and structurally related peptides in quiescent Swiss 3T3 cells. I. Activation of protein kinase $\mathrm{C}$ and inhibition of epidermal growth factor binding. J. Cell Biol. 102:2211-2222.

24. Wakelam, M. J. O., S. A. Davies, M. D. Houslay, I. McKay, J. Christopher, and A. Hall. 1986. Normal p21 N-ras couples bombesin and other growth factor receptors to inositol phosphate production. Nature (Lond.). 323:173-176.

25. Lehy, T., F. Puccio, J. Chariot, and D. Labeille. 1986. Stimulating effect of bombesin on the growth of gastrointestinal tract and pancreas in suckling rats. Gastroenterology. 90:1942-1949.

26. Lehy, T., F. Puccio, J. Chariot, L. Gres, and M. Lewin. 1985. Influence of rGRF and bombesin on the growth of lung and digestive tract in suckling rats. In Regulatory Peptides in Digestive, Nervous and Endocrine Systems. M. J. Lewin and S. Bonfils, editors. Elsevier Science Publishers, Amsterdam. 413-416.

27. Chirgwin, J. M., A. E. Przybyla, R. J. MacDonald, and W. J. Rutter. 1979. Isolation of biologically active ribonucleic acid from sources enriched in ribonuclease. Biochemistry. 18:5294-5299.

28. Manatis, T., E. F. Fritsch, and J. Sambrook. 1982. Molecular Cloning, A Laboratory Manual. Cold Spring Harbor Laboratories, Cold Spring Harbor, NY.

29. Spindel, E. R., W. W. Chin, J. Price, L. H. Rees, G. M. Besser, and J. F. Habener. 1984. Cloning and characterization of cDNAs encoding human gastrin-releasing peptide. Proc. Natl. Acad. Sci. USA. 81:5699-5703.

30. Melton, D. A., P. A. Krieg, M. R. Rebagliati, T. Maniatis, K. Zinn, and M. R. Green. 1984. Efficient in vitro synthesis of biologically active RNA and RNA hybridization probes from plasma containing a bacteriophage SP6 promoter. Nucleic Acids Res. 12:70357056.

31. Battey, J., C. Moulding, R. Taub, W. Murphy, T. Stewart, H. Potter, G. Lenoir, and P. Leder. 1983. The human c-myc oncogene: structural consequences of translocation into the IgH locus in Burkitt lymphoma. Cell. 34:779-787.

32. Hofler, H., H. Childers, M. R. Montminy, R. Lechan, R. H. Goodman, and H. Wolfe. 1986. In situ hybridization methods for the detection of somatostatin mRNA in tissue secretions using antisense RNA probes. J. Histochem. 18:597-604.

33. Stahlman, M. T., and M. E. Gray. 1984. Ontogeny of neuroendocrine cells in human fetal lung. I. An electron microscopic study. Lab. Invest. 51:449-463.

34. Reid, L. M. 1984. Lung growth in health and disease. Br. J. Dis. Chest. 78:113-134.

35. Price, J., E. Penman, G. L. Bourne, and L. H. Rees. 1983. Characterization of bombesin-like immunoreactivity in human fetal lung. Regul. Pept. 7:315-322.

36. Hsu, S., L. Raine, and H. Fanger. 1981. A comparative study of the peroxidase-antiperoxidase method and an avidin-biotin complex method for studying polypeptide hormones with radioimmunoassay antibodies. J. Clin. Pathol. (Lond.). 75:734-738.

37. Lloyd, R. V., and B. S. Wilson. 1983. Specific endocrine tissue marker defined by a monoclonal antibody. Science (Wash. DC). 222:625-630.

38. Boyden, E. A. 1977. Development and growth of the airways. In Development of the Lung. W. A. Hobson, editor. Marcel Dekker, Inc., New York. 3-36.

39. Ekman, R., and I. M. Keith. 1986. Calcitonin gene-related peptide (CGRP), peptide YY (PYY), gastrin-releasing peptide (GRP) and other in hamster lung and plasma. Fed. Proc. 45:795. 